\title{
Pendidikan Kecakapan Hidup Melalui Pelatihan Produktivitas Menciptakan Barang dan Jasa bagi Siswa Madrasah Aliyah di Purwakarta
}

\author{
Usep Setiawan, Ade Irvi Nurul Husna* \\ STAI Dr. KH. EZ. Muttaqien, Indonesia \\ ade.irvi.nurul@gmail.com*
}

\begin{abstract}
Abstrak
Pendidikan kecakapan hidup bertujuan untuk meningkatkan pemahaman mengenai kecakapan hidup dan pola pikir serta meningkatkan keterampilan dan pengalaman dalam kegiatan produksi baik barang maupun jasa agar tumbuh keinginan berwirausaha khususnya bagi siswa Madrasah Aliyah dan masyarakat usia produktif pada umumnya. Pendidikan kecakapan hidup dilakukan dalam dua tahap dengan metode seminar dan workshop. Tahap pertama yaitu presentasi. Tahap ini berupa pemaparan mengenai pentingnya memiliki kecakapan hidup dan mengambangkan pola pikir agar terbuka lebih luas kepada para peserta. Tahap kedua yaitu produksi. Tahap kedua melibatkan partisipan dalam melakukan kegiatan pelatihan produksi berupa barang dan jasa. Hasil dari kegiatan pendidikan mengenai kecakapan hidup ini menunjukkan adanya peningkatan pemahaman partisipan mengenai kecakapan hidup dan pola pikir serta pengembangan keterampilan pada proses produksi. Berdasar hasil analisis dari data wawancara mengungkapkan bahwa pemahaman mengenai kecakapan hidup, pola pikir, dan keterampilan meningkat karena partisipan telah memperoleh pemahaman dan juga pengalaman secara langsung dengan melakukan kegiatan produksi.
\end{abstract}

Kata kunci : Kecakapan Hidup; Madrasah Aliyah; Pendidikan

\begin{abstract}
Life Skills Education aims to increase understanding of life skills and mindset as well as increase skills and experience in the production of goods and services in order to grow entrepreneurial desires especially for Madrasah Aliyah students and the productive age community in general. Life skills education is carried out in two stages using the seminar and workshop methods. The first step is presentation. This stage is in the form of presentation about the importance of having life skills and developing a mindset to be more open to the participants. The second stage is production. The second stage involves participants in conducting production training activities in the form of goods and services. The results of this educational activity on life skills show an increase in participants' understanding of life skills and mindset and skills development in the production process. Based on the results of the analysis of the interview data revealed that understanding of life skills, mindset, and skills improved because participants had gained understanding and also direct experience with conducting production activities.

Keywords: Life Skills; Madrasah Aliyah; Education
\end{abstract}




\section{PENDAHULUAN}

Siswa Madrasah Aliyah merupakan siswa pendidikan setara menengah atas yang termasuk ke dalam kelompok usia produktif yaitu 15-64 tahun (Bappenas, 2019) dan akan menjalani kehidupan dengan persaingan yang sebenarnya setelah lulus sekolah nanti. Jumlah penduduk pada kelompok usia produktif yang berada di Indonesia cukup mendominasi yaitu dengan jumlah sebesar 68,7 persen (BPS, 2019). Data tersebut menunjukkan cukup besarnya jumlah masyarakat yang secara ideal dapat melakukan usaha mandiri dalam rangka meningkatkan taraf hidupnya. Namun berdasar data BPS Provinsi Jawa Barat pada tahun 2018, Tingkat Pengangguran Terbuka atau TPT di Jawa Barat menunjukkan angka sebesar 8,17 persen dan bahkan di Kabupaten Purwakarta sebesar 9,89 persen di mana angka ini jauh melebihi TPT tingkat nasional yang berada di besaran 5,34 persen (Wicaksono, 2020). Berdasarkan data jumlah peserta didik di Madrasah Aliyah Kabupaten Purwakarta Tahun Ajaran 2019/2020 tercatat ada sekitar 1,4 juta santri (Kemenag, 2020) yang sedang memperoleh pendidikan di mana akan melahirkan lulusan setiap tahunnya yang diharapkan tidak menambah jumlah pengangguran di Indonesia khususnya di Kabupaten Purwakarta.

Dinamika zaman yang terus berubah-ubah dan mengalami kemajuan serta perkembangan dari segi ilmu, pengetahuan, informasi, dan teknologi menjadi salah satu alasan pentingnya bagi seseorang memiliki kecakapan hidup. Persaingan global yang ada di depan mata tidak bisa dihindarkan melainkan untuk dihadapi secara umum oleh masyarakat usia produktif dan khususnya oleh para siswa Madrasah Aliyah di mana akan menghadapi persaingan yang sebenarnya. Setiap individu dituntut untuk memperoleh pendidikan baik formal maupun nonformal yang akan bermanfaat bagi kehidupannya. Kebutuhan hidup dari waktu ke waktu semakin meningkat, senantiasa akan memberikan tekanan hebat pada kondisi seseorang dalam menjalani kehidupan ekonomi-sosialnya. Apalagi jika tidak dibarengi dengan kemampuan dalam mengadaptasikan diri dari segala perubahan yang terjadi, maka kita hanya bisa menjadi penonton di rumah sendiri. Atas adanya hal tersebut maka siswa madrasah ditantang untuk beradaptasi pada perkembangan informasi dan teknologi yang begitu cepat dan siap dalam keterlibatannya (Supriatna, 2017).

Pendidikan yang dibutuhkan oleh masyarakat dalam menjalani kehidupan bukan hanya pada pendidikan formal saja tetapi juga pendidikan nonformal yang memiliki dasar kecakapan hidup (life skills). Out put pendidikan formal yang kurang memiliki keterampilan, sebagian dapat dilengkapi dengan keterampilan untuk dapat bekerja pada instansi negeri dan swasta, atau mengembangkan usaha mandiri (wirausaha), siswa yang putus sekolah dan tidak sempat mengikuti pendidikan formal diberikan kesempatan untuk mengikuti pendidikan nonformal (program pendidikan kecakapan hidup atau life skill) sehingga mampu meningkatkan taraf hidupnya (Herlinda, 2017). Sehingga jika seseorang hanya memperoleh pendidikan formal saja tidak menjadi jaminan bahwa ia dapat menjadi masyarakat yang mandiri tanpa didukung pendidikan nonformalnya. Adaptasi terhadap lingkungan yang sekarang ini semakin berkembang perlu dukungan pendidikan nonformal yaitu salah satunya dengan memahami pentingnya kecakapan hidup dan mengembangkan pola pikir.

Kecakapan hidup memiliki pengertian yang lebih luas dari sekedar keterampilan bekerja. Kecakapan hidup menurut Tim Broad-Based Education (2002) merupakan kecakapan yang dimiliki seseorang untuk mau dan berani menghadapi permasalahan hidup dan kehidupan secara wajar tanpa merasa tertekan, kemudian secara proaktif dan kreatif mencari serta menemukan solusi sehingga akhirnya mampu mengatasinya (Sholikul A, 2015). Pendidikan kecakapan hidup mempunyai spektrum yang sangat luas baik subjek dan objeknya, sehingga perlu adanya sasaran peserta sehingga tepat dalam memberikan keterampilan bekerja dan mendorong peserta berusaha mandiri dengan tujuan akhir untuk meningkatkan pendapatan, kesejahteraan dan produktivitas hidup masyarakat marginal dalam meningkatkan kemampuan sosial ekonominya (Sutisna, 2016). 
Melihat latar belakang di atas, pendidikan kecakapan hidup ini relevan diterapkan kepada masyarakat umumnya pada masyarakat kelompok usia produktif. Hal ini sesuai dengan Undang-Undang nomor 20 tahun 2003 tentang Sistem Pendidikan Nasional pasal 26 ayat 3 bahwa Pendidikan nonformal meliputi salah satunya yaitu pendidikan kecakapan hidup, dan lainnya yaitu pendidikan anak usia dini, pendidikan kepemudaan, pendidikan pemberdayaan perempuan, pendidikan keaksaraan, pendidikan keterampilan dan pelatihan kerja, pendidikan kesetaraan, serta pendidikan lain yang ditujukan untuk mengembangkan kemampuan peserta didik.

Pendidikan ini dapat bermanfaat bagi masyarakat untuk membentuk individu yang mandiri, terbentuknya karakter masyarakat yang memiliki kecakapan hidup yang berdaya guna dan berdaya saing tinggi. Keterampilan yang diperoleh masyarakat pada kegiatan pendidikan kecakapan hidup juga dapat ditularkan kembali kepada khalayak sebagai upaya menurunkan tingkat pengangguran terutama di daerah pedesaan. Kegiatan pendidikan ini dapat dijadikan sebagai wadah dalam menyalurkan pengetahuan dan memberikan perubahan yang lebih baik kepada masyarakat.

\section{METODE}

Kegiatan pendidikan kecakapan hidup dilaksanakan menggunakan metode seminar dan workshop. Sasaran peserta dalam kegiatan pendidikan ini dibatasi agar kegiatan dapat menghasilkan out put yang sesuai dengan rencana sehingga peserta pada kegiatan masyarakat ini adalah: (1) Pemuda/I usia minimal 17 tahun diutamakan yang sudah tidak melanjutkan pendidikan; (2) Bapak-bapak dan Ibu-ibu usia produktif yang tidak memiliki pekerjaan tetap atau serabutan; (3) Siswa/I MA/Sederajat kelas XII di Kabupaten Purwakarta. Tempat kegiatan pendidikan kecakapan hidup yang dilakukan berada di dua lokasi Madrasah Aliyah yaitu Al-Fatah, Tegal Waru dan Miftahul Ulum, Darangdan.

Ada dua tahapan dalam kegiatan pendidikan kecakapan hidup yang dilakukan. Tahap pertama merupakan kegiatan presentasi. Pada kegiatan presentasi ini memuat sesi pemaparan dan diskusi atau tanya jawab mengenai pentingnya memiliki kecakapan hidup dan upaya dalam mengembangkan pola pikir. Hal ini dilakukan agar peserta dapat mengembangkan pola pikir secara lebih terbuka dan melihat berbagai persoalan dengan lebih luas. Pada tahap pertama kegiatan diawali dengan meminta peserta untuk menuliskan keterampilan, keahlian, atau kompetensi yang dimiliki oleh dirinya dalam selembar kertas tanpa diberi keterangan nama. Hal ini bertujuan untuk mengetahui sejauh mana pengenalan akan keahlian diri sendiri dari para peserta. Selanjutnya kertas dikumpulkan kepada panitia kegiatan. Kegiatan kemudian dilanjutkan dengan pemaparan materi mengenai nilai penting pendidikan kecakapan hidup (life skill) serta perubahan dan peranan pola pikir (mind set) masyarakat akan berwirausaha. Pada tahap ini yaitu kegiatan presentasi, selain pemaparan juga adanya sesi diskusi atau tanya-jawab dengan para peserta. Para peserta diberi kesempatan untuk bertanya dan mengutarakan keluhan yang menjadi hambatan berkaitan dengan permasalahan kecakapan hidup dan pola pikir yang dialaminya. Dalam tahap pertama diberikan juga masukan dan saran kepada para peserta untuk memilih jenis kegiatan produksi yang akan dilakukan pada tahap berikutnya sesuai dengan kebutuhan, kemampuan, dan peminatan peserta.

Selanjutnya yaitu tahap kedua yang merupakan kegiatan produksi berupa workshop atau pelatihan dengan melibatkan para peserta dalam melakukan berbagai jenis kegiatan produksi baik barang maupun jasa. Pada tahap kedua yaitu produksi ini pelatihan dilaksanakan sesuai dengan minat peserta yang sudah dipilih ketika peserta akan memasuki tahap kedua. Pemilihan minat pada kegiatan produksi ini dilakukan diawal tahap kedua agar peserta memiliki gambaran mengenai proses pelatihan dan produk apa yang akan dibuatnya nanti. Hal ini diharapkan agar peserta mampu membuat hasil produksi dengan senang hati dan juga hasil produk yang berkualitas. Para peserta praktik secara langsung dalam membuat berbagai produk 
barang maupun jasa. Tahap kedua kegiatan workshop peserta pelatihan dibagi ke dalam beberapa kelompok keahlian sebagai berikut: (a) Kelompok peserta pelatihan membuat donat; (b) Kelompok peserta pelatihan membuat gantungan kunci; (c) Kelompok peserta pelatihan editing film sederhana; (d) Kelompok peserta pelatihan jasa tata rias atau make up; (e) Kelompok peserta pelatihan membuat pot bunga dari keramik; (f) Kelompok peserta pelatihan membuat hiasan bunga.

Di akhir tahap kedua setelah selesai pelatihan kegiatan produksi, peserta menerima saran dan masukkan yang membangun yang berasal dari dosen tim pengabdi dan juga peserta lainnya. Setelah itu kegiatan pendidikan kecakapan hidup ditutup secara resmi dengan foto bersama dan pembagian sertifikat untuk para peserta.

\section{HASIL DAN PEMBAHASAN}

Pendidikan kecakapan hidup dilaksanakan dalam dua tahapan dan di dua lokasi yang berbeda. Kegiatan dilaksanakan pada tanggal 15 Januari 2020 berlokasi di Madrasah Aliyah Al-Fatah, Tegal Waru dan tanggal 30 Januari 2020 di Madrasah Aliyah Miftahul Ulum, Darangdan Kabupaten Purwakarta. Peserta yang mengikuti kegiatan pendidikan kecakapan hidup ini yaitu: (1) Pemuda/I usia minimal 17 tahun diutamakan yang tidak melanjutkan pendidikan; (2) Bapak-bapak dan Ibu-ibu usia produktif yang tidak memiliki pekerjaan tetap atau serabutan; (3) Siswa/I MA/ Sederajat kelas XII. Secara umum kegiatan ini diikuti sesuai dengan sasaran kegiatan yakni oleh masyarakat usia produktif dan khususnya siswa Madrasah Aliyah.

Permasalahan yang menjadi keluhan dari siswa Madrasah Aliyah melalui pengumpulan data dengan wawancara yaitu ketakutan akan pekerjaan atau profesi ketika nanti siswa telah menyelesaikan pendidikan formalnya. Permasalahan yang sama juga dihadapi oleh masyarakat secara umum yang berada pada kelompok usia produktif baik yang sudah berumah tangga maupun masyarakat yang tidak bisa melanjutkan pendidikan formalnya. Hal ini tentu menjadi kendala di masyarakat kelompok usia produktif, yang diakui oleh sebagian besar dari peserta pelatihan.

Keterbatasan keterampilan, ilmu, pengetahuan, dan teknologi informasi serta pengalaman karena alasan akses, jaringan, dan keuangan yang kurang mumpuni. Hal tersebut mengakibatkan kemampuan kecakapan hidup yang dimiliki tidak mengalami peningkatan. Sejumlah pengakuan dari peserta mereka merasakan tidak banyak memperoleh pelatihan keterampilan dan ilmu pengetahuan mengenai hal-hal baru yang dapat meningkatkan kecakapan hidupnya dari tahun ke tahun. Life skill yang mereka miliki dirasa tetap dan tidak ada perkembangan, sehingga mereka tidak dapat mengambil peluang baik bekerja maupun berwirausaha. Beberapa contoh seperti adanya peluang kerja tetapi mereka tidak bisa mengakses informasinya, terbukanya peluang usaha tetapi mereka tidak dapat melakukan usaha tersebut karena keterbatasan modal baik keuangan maupun jaringan pemasaran. Alasan yang lebih mendominasi dari kurangnya kecakapan hidup ini yaitu pola pikir yang masih terbatas dan kurang berkembang. Di samping pola pikir, juga terdapat alasan motivasi yang masih rendah dari peserta pelatihan namun alasan motivasi ini hanya terdapat $20 \%$ saja dari peserta.

Kendala lain yang ditemukan melalui wawancara dan observasi yaitu banyaknya peserta baik siswa maupun umum yang tidak memahami kelebihan yang dimiliki dirinya sendiri. Hal ini menjadi satu kendala yang penting karena dengan ketidakpahaman akan kelebihan diri maka tidak dapat mengembangkan kemampuannya. Sebagai bukti adalah ketika partisipan ditanya satu persatu apa yang menjadi kelebihan dirinya maka yang tampak pada mereka yaitu terdiam, berpikir, menggelengkan kepala, mengangkat bahu, dan tersenyum tanpa ada jawaban lisan. Hanya sebagian kecil saja dari mereka yang menjawab mengenai kelebihan dirinya. Berdasarkan hasil wawancara peserta ketidakpahaman mengenai kelebihan diri karena 
tidak membiasakan diri mengerjakan hal yang disukai dan dapat memberikan manfaat baik yang bersifat profit maupun non-profit.

Kendala-kendala yang dialami partisipan memunculkan pernyataan-pernyataan yang menunjukkan indikasi-indikasi sebagai berikut: 1) banyak kalangan siswa dan umum yang tidak mengembangkan kemampuan yang dimilikinya; 2) siswa memiliki kecemasan akan pekerjaan setelah lulus; 3) kecemasan khalayak umum akan kemampuannya menghadapi persaingan secara ekonomi. Kurangnya pemahaman mengenai kecakapan hidup dan pola pikir dapat menimbulkan kekhawatiran pada siswa maupun masyarakat umum dalam menghadapi tantangan hidup. Hasil analisis berdasarkan wawancara, siswa menjadi kurang kreatif dan inovatif karena hanya melakukan hal yang diperintahkan saja.

Keterbatasan informasi mengenai adanya kegiatan pelatihan dan pengembangan diri menjadi kesulitan bagi siswa dan masyarakat umum dalam mengembangkan kecakapan hidup. Agar siswa dan masyarakat dapat meningkatkan pemahaman mengenai kecakapan hidup yaitu lembaga pendidikan baik formal maupun nonformal harus mengadakan suatu kegiatan yang berkaitan dengan pengembangan diri siswa dan masyarakat mengenai kecakapan hidup, pola pikir, dan keterampilan. Bila ada lembaga yang melaksanakan kegiatan pengembangan diri dan pelatihan perlu juga didukung dengan hal yang dapat menunjang lainnya seperti modal keuangan, pelatihan keuangan, akses jaringan pemasaran, pembinaan, dan pendampingan. Hal ini ditujukan untuk meningkatkan pemahaman mengenai kecakapan hidup dan pola pikir serta meningkatkan keterampilan dan pengalaman dalam kegiatan produksi baik barang maupun jasa agar tumbuh keinginan berwirausaha sehingga menjadi masyarakat yang mandiri.

Khusus mengenai pendidikan kecakapan hidup yang menjadi kebutuhan bagi partisipan perlu memerhatikan beberapa hal berikut yaitu: 1) informasi mengenai pelaksanaan kegiatan dapat diterima oleh siswa dan umum; 2) lokasi kegiatan dapat dijangkau ; 3) materi setiap sesinya menarik perhatian dan kejelasan dalam diskusi; 4) penggunaan bahasa yang sederhana dan mudah dipahami; 5) menumbuhkan motivasi untuk berubah lebih baik lagi; 6) menggunakan teknologi yang kekinian; 7) mendorong siswa dan masyarakat umum memiliki keterampilan yang dapat bermanfaat baik orientasi profit maupun nonprofit.

Kegiatan pendidikan kecakapan hidup menurut partisipan yang utama perlu diperhatikan yaitu menarik, pengunaan teknologi, dan mendorong pada perubahan yang lebih baik. Pelaksanaan kegiatan pendidikan kecakapan hidup bagi siswa secara khusus dan masyarakat umum dilakukan melalui dua tahapan, tahap pertama yaitu presentasi untuk memaparkan materi mengenai pentingnya kecakapan hidup (life skill) dan pengembangan pola pikir (mindset). Setelah pemaparan materi ada sesi diskusi dan tanya jawab seputar kecakapan hidup. Kegiatan tahap dua dilanjutkan dengan workshop atau praktik pelatihan memproduksi barang maupun jasa. Partisipan dibuat berkelompok ketika workshop sesuai dengan minat produk pelatihannya. Setelah partisipan memahami cara pembuatan produk selanjutnya diberi kesempatan untuk membuat sendiri agar lebih terlatih.

Keterampilan membuat produk pada tahap workshop disesuaikan dengan minat peserta. Materi pada tahap pertama yaitu presentasi mengenai pentingnya kecakapan hidup dan mengembangkan pola pikir menjadi suatu pemacu motivasi peserta dalam kegiatan tahap kedua. Sebagai penyemangat peserta diberi kesempatan menyampaikan pesan dan kesannya setelah selesai melakukan kedua tahap kegiatan pendidikan kecakapan hidup ini yang disampaikan kepada peserta lainnya. Hal ini dimaksudkan agar setiap peserta memiliki pemahaman terhadap pentingnya kecakapan hidup dan pola pikir.

Pelaksanaan kegiatan pendidikan kecakapan hidup berjalan sesuai dengan agenda yang tertulis, semuanya sesuai dengan rencana yang telah disusun, berjalan dengan sangat kondusif, dan menyenangkan. Hal ini berdasar atas ucapan dari para peserta pada kegiatan penutupan, masing-masing peserta diberi waktu untuk memberikan tanggapannya mengenai kegiatan tersebut. Pada prinsipnya acara pun terlaksana 
dengan penuh khidmat. Antusiasme peserta pun luar biasa bagus dan bersemangat. Peserta juga konsisten dalam mengikuti kegiatan mulai tahap pertama dan kedua yaitu dari teori hingga praktek.

Pelaksanaan kegiatan pendidikan kecakapan hidup dengan dua tahap dilakukan evaluasi dengan menyebar angket. Berdasarkan hasil angket partisipan mengalami peningkatan setelah mengikuti kegiatan pendidikan kecakapan hidup. Peningkatan tersebut diantaranya peningkatan pengetahuan dan pemahaman, motivasi, serta keterampilan melakukan produksi. Misalnya pada pernyataan setelah dilakukan kegiatan pendidikan kecakapan hidup tahap kedua yaitu workshop menunjukkan rata-rata skor peningkatan $65 \%$ setelah dilakukan workshop. Hal lainnya yaitu pada pernyataan setelah dilakukan kegiatan pendidikan kecakapan hidup bagian pertama yaitu presentasi menunjukkan rata-rata skor kategori tinggi pada peningkatan pengetahuan dan pemahaman pentingnya life skill dan mindset. Hal tersebut menunjukkan motivasi peserta untuk mengikuti pelatihan dan materi yang diterima sudah baik. Namun masih dibutuhkan kegiatan pendidikan kecakapan hidup lanjutan untuk siswa dan masayrakat umum di Kabupaten Purwakarta.

Gambar 1. Presentasi Penyampaian Materi

Gambar 2. Workshop Membuat Kecakapan Hidup Gantungan Kunci

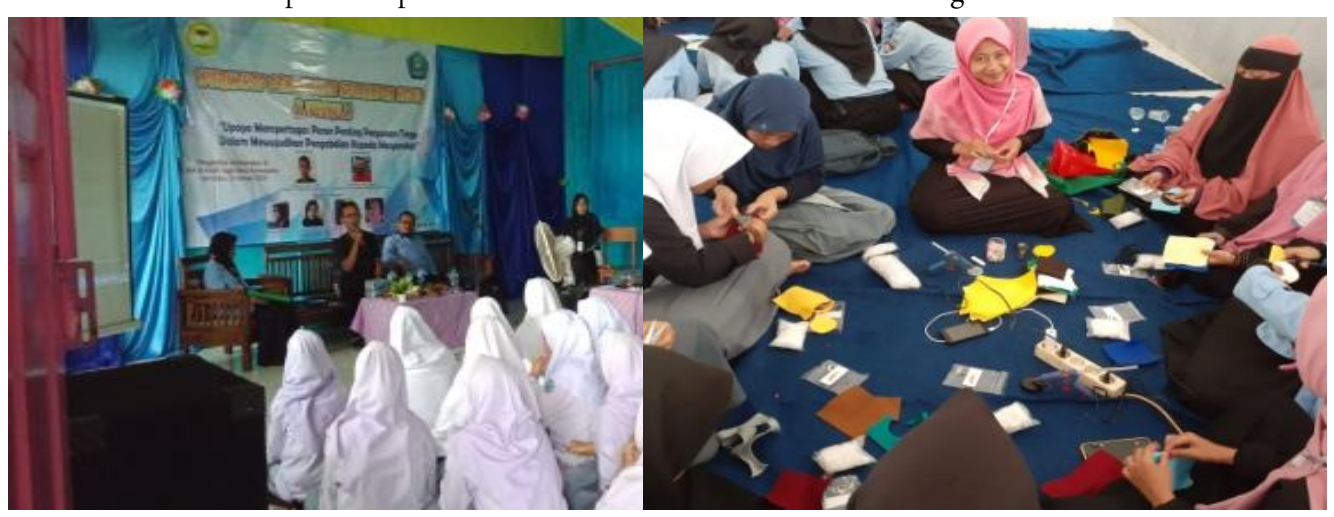

\section{KESIMPULAN}

Hasil pendidikan kecakapan hidup ini menunjukkan bahwa peningkatan pengetahuan dan pemahaman serta keterampilan dalam hal produksi baik barang maupun jasa terlaksana dengan efektif. Dua tahap kegiatan berupa presentasi dan workshop dengan sejumlah sesi ini berhasil meningkatkan pengetahuan dan pemahaman partisipan. Keterampilan dalam melakukan produksi partisipan juga mengalami peningkatan. Hal ini dapat berarti jika pendidikan nonformal berdasar kecakapan hidup bisa dilakukan secara konsisten dan berkualitas maka akan memberikan peningkatan pengetahuan dan pemahaman mengenai kecakapan hidup (life skill) dan pola pikir (mind set) serta kompetensi masyarakat usia produktif secara umum dan khususnya siswa Madrasah Aliyah.

Keterbatasan pada kegiatan pendidikan kecakapan hidup ini yaitu hanya menyasar pada masyarakat di lingkungan Madrasah Aliyah Kabupaten Purwakarta saja sementara permasalahan berkaitan dengan kecakapan hidup terjadi pada wilayah lainnya. Kegiatan pelatihan Memberikan motivasi kepada masyarakat dalam aktivitas pelatihan berikutnya sebaiknya mempertimbangkan motivasi dan permodalan.

\section{UCAPAN TERIMA KASIH}

Terima kasih kami ucapkan kepada sejumlah pihak yang turut membantu atas kelancaran kegiatan ini, diantarnya Ketua dan seluruh rekan STAI Dr. KH. EZ. Muttaqien, Kepala Madrasah Aliyah Al-Fatah, 
Tegal Waru, dan Kepala Madrasah Aliyah Miftahul Ulum, Darangdan Kabupaten Purwakarta. Juga terima kasih kepada semua pihak yang telah turut membantu baik materil maupun imateril atas terselenggaranya kegiatan pengabdian kepada masyarakat yang kami laksanakan.

\section{DAFTAR RUJUKAN}

Bappenas, B. (2019). Jumlah Penduduk Indonesia 2019. Bappenas (p. 1). Retrieved from https://databoks.katadata.co.id/datapublish/2019/01/04/jumlah-penduduk-indonesia-2019mencapai-267-juta-jiwa

BPS, B. (2019). Jumlah Penduduk Indonesia 2019 Mencapai 267 Juta Jiwa.

Herlinda, S., Hidayat, S., \& Djumena, I. (2017). Manajemen Pelatihan Hantaran dalam Meningkatkan Kecakapan Hidup Warga Belajar di Lembaga Kursus dan Pelatihan. Journal of Nonformal Education and Community Empowerment, 1(1), 1-9. https://doi.org/10.15294/pls.v1i1.14758

Kemenag, K. (2020). Rekapitulasi Data Pokok Pendidikan Islam. Retrieved from emispendis.kemenag.go.id Munandar, T. A., Harsiti, H., \& Sugiyani, Y. (2018). Peningkatan Kemandirian Perekonomian Masyarakat melalui Program Desa Vokasi Berbasis Kecakapan Hidup dan Pendidikan Kewirausahaan Masyarakat. Wikrama Parahita: Jurnal Pengabdian Masyarakat, 2(1), 14. https://doi.org/10.30656/jpmwp.v2i1.404

Mustadi, A., Wangid, M. N., Zubaidah, E., \& Irvan, M. F. (2019). Pelatihan Pembuatan Media Pembelajaran Literasi Kelas Awal bagi Guru SD. CARADDE: Jurnal Pengabdian Kepada Masyarakat, 2(2), 203-208. https://doi.org/10.31960/caradde.v2i2.330

Sholikul A., \& Sutarto J. (2015). Pelaksanaan Pembelajaran Program Pendidikan Kecakapan Hidup (Pelatihan Life Skill Computer di Pondok Pesantren Salafiyyah Roudlotul Mubtadiin Balekambang Jepara Tahun 2015). Journal of Nonformal Education and Community Empowerment, 4(2).

Supriatna, R. D., \& Ratnaningsih, S. (2017). Indonesian Madrasah in the Era of Globalization. TARBIYA: Journal of Education in Muslim Society, 4(1), 89-103. https://doi.org/10.15408/tjems.v4i1.5908

Sutarto J., Mulyono, S. E., Nurhalim, K., \& Pratiwi, H. (2018). Model Pemberdayaan Masyarakat Melalui Pelatihan Kecakapan Hidup Berbasis Keunggulan Lokal Desa Wisata Mandiri Wanurejo Borobudur Magelang. Jurnal Penelitian Pendidikan, 35(1), 27-40. https://doi.org/10.15294/jpp.v35i1.15091

Sutisna, N. (2016). Pemberdayaan Penca Pasca Sekolah Melalui Kecakapan Hidup. JASSI ANAKKU, $9(2)$, 184-190.

Undang-Undang Republik Indonesia Nomor 20 Tahun 2003 tentang Sistem Pendidikan Nasional. Jakarta : Departemen Pendidikan Nasional Republik Indonesia.

Wicaksono, B. R., \& Kharisma, B. (2020). Kemiskinan Dan Ketenagakerjaan Di Jawa Barat: Studi Kasus Kabupaten Purwakarta. E-Jurnal Ekonomi Dan Bisnis Universitas Udayana, 1. https://doi.org/10.24843/eeb.2020.v09.i01.p01 